\title{
Ultrastructure of fresh and post thawed sperm of pejerrey Odontesthes bonariensis (Atheriniformes)
}

\author{
Ángela Gárriz and Leandro A. Miranda
}

In the present study it was showed for the first time the ultrastructural morphology of $O$. bonariensis sperm using electron microscopy techniques. Different kinds of abnormalities were described in fresh and post thawed sperm caused by crogenic protocols. Pejerrey spermatozoon is uniflagellated and is differentiated into three parts: a small roundish head $(\sim 1.80 \mu \mathrm{m}$ in length and $1.67 \mu \mathrm{m}$ in width), a midpiece or transitional region $(\sim 1.11 \mu \mathrm{m}$ in length and $1.56 \mu \mathrm{m}$ in width), and a long tail or flagellum $(\sim 29.08 \mu \mathrm{m})$. Samples of fresh and post thawed sperm showed evidence of morphological anomalies affecting various intracellular compartments. Spermatozoa with swollen, ruptured, or absent membranes in the head showing excess of cytoplasm, and with alteration of the spatial orientation of the mitochondria were observed. A swollen flagellum was observed containing cytoplasmic vesicles, distributed along the whole length or concentrated in a restricted part of the tail. It was also found a high level of abnormalities $(60 \%)$ in frozen sperm when compared with normal sperm $(18 \%)$ reflecting the damage provoked by cryopreservation procedures.

No presente estudo mostrou-se pela primeira vez a morfologia estrutural dos espermatozoides de $O$. bonariensis utilizando técnicas de microscopia eletrônica. Diferentes tipos de anormalidades foram descritas para sêmen fresco e descongelado. O espermatozoide de Pejerrey é uniflagelado e dividido em três partes: uma cabeça pequena e arredondada $(\sim 1.80 \mu \mathrm{m}$ de comprimento e $1.67 \mu \mathrm{m}$ de largura), uma parte intermediária ou região de transição $(\sim 1.11 \mu \mathrm{m}$ de comprimento e $1.56 \mu \mathrm{m}$ de largura $)$ e uma cauda longa ou flagelo $(\sim 29.08 \mu \mathrm{m})$. Amostras de sêmen fresco e descongelado mostraram evidências de anormalidades morfológicas afetando vários compartimentos intracelulares. $\mathrm{Na}$ cabeça haviam espermatozoides com membranas dilatadas, rompidas ou ausentes, mostrando excesso de citoplasma e alteração na orientação espacial das mitocôndrias. Um flagelo dilatado foi observado contendo vesículas citoplasmáticas, as quais estavam distribuídas ao longo de todo o seu comprimento ou concentradas em uma parte restrita da cauda. Também foi encontrado um alto nível de anormalidades $(60 \%)$ em sêmen congelado em comparação com o sêmen normal (18\%), refletindo os danos provocados pelos procedimentos de criopreservação.

Key words: Cryopreservation, Morphology.

\section{Introduction}

Atheriniformes are widespread, abundant and ecologically important forage fishes in near-shore marine, estuarine, and freshwater habitats (Bloom et al., 2012). Pejerrey (Odontesthes bonariensis) is an inland water fish native from Buenos Aires Province (Argentina) and the South of Brazil (Dyer, 2006). It is a brackish species (Tsuzuki et al., 2000) considered the largest atheriniform in the world (Dyer \& Chernoff, 1996). This species is highly appreciated because of the quality of its flesh and also as a game fish, and probably is the most popular and known fish in Argentina (López et al., 2001). Although, pejerrey aquaculture is considered regionally important, it has not been fully developed (Somoza et al., 2008). One technical problem is the obtaining of enough number of embryos for the operation of a hatchery in an efficient way. For this purpose, it was necessary to solve some reproductive aspects like the marked asynchrony between females during spawning season, the relatively low fecundity, and the low volume of expressible milt (Strüssmann, 1989; Miranda et al., 2001). For these reasons, some experiments were performed using environmental and hormonal treatments to increase pejerrey sperm volume and synchronize spawning in females (Miranda et al., 2001, 2005, 2006; Miranda \& Somoza, 2009). Recently, pejerrey sperm have been successfully cryopreserved using simple and reliable techniques which produced thawed 


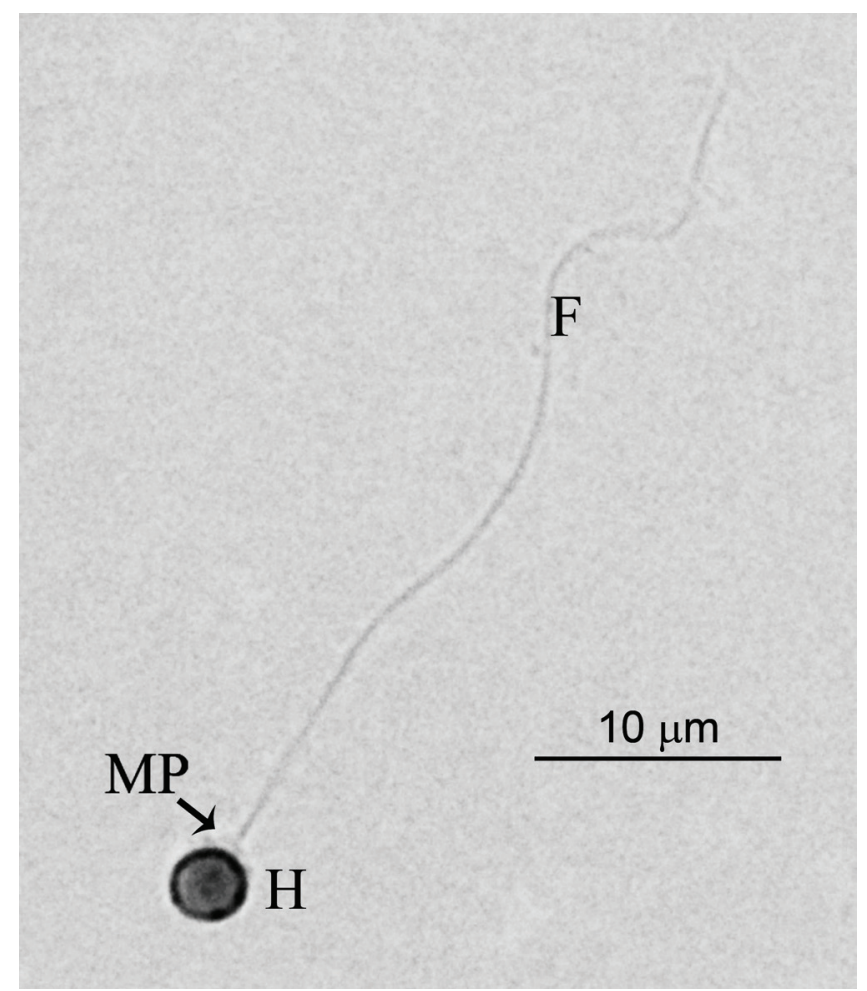

Fig. 1. Fresh pejerrey spermatozoa stained with eosin. H: Head; MP: Midpiece; F: Flagellum.

spermatozoa capable of fertilizing oocytes with values between $44-80 \%$ depending on the method used. In that study, the best results were obtained using a saline based solution as extender, dimethyl sulfoxide (DMSO) or ethylene glycol (EG) as cryoprotectants, and liquid $\mathrm{N}_{2}$ as freezing method (Lichtenstein et al., 2010). These values, demonstrated that cryopreservation affected viability and fertilizing capacity of frozen thawed spermatozoa.

In the last years, great emphasis has been placed on the study of the effects of cryosolutions and cooling procedures on the structure and physiology of spermatozoa (Lahnsteiner et al., 1996; Cabrita et al., 1998; Rodriguez-Martinez et al., 1998, Yao et al., 2000). It has been observed that different types of alterations and damages could be provoked or increased by cryopreservation procedures. For example, ruptured plasmatic membranes in the spermatozoa head, midpiece, and flagellum, as well as swollen mitochondria and broken axoneme were frequently found after thawing (Gwo et al., 1992; Lahnsteiner et al., 1996; Yao et al., 2000; Taddei et al., 2001). Besides, the examination of sperm morphology at ultrastructural level provides useful information to develop cryopreservation protocols (He \& Woods, 2004), and also for doing phylogenetic analysis; Mattei, 1991; Gwo et al., 2004a, b; França et al., 2007; Jamieson, 2009). Between the methods that are used to investigate cellular damages, electron microscopy techniques provide detailed information on the subcellular ultrastructure representing a useful tool for the evaluation of morphological changes that can affect sperm functionality (Taddei et al., 2001).

In order to analyze the damage produced during freezing procedures, and due to the lack of information about pejerrey spermatozoa morphology, in this study we investigated the anomalies caused by cryogenic protocols at ultrastructural level.

\section{Material and Methods}

\section{Milt collection and cryopreservation procedure}

Pejerrey male spawners reared at IIB-INTECH aquaculture facilities were used during spawning season (spring). They were kept in $3000 \mathrm{~L}$ indoors tanks with an open flow system keeping water temperature and salinity around $18^{\circ} \mathrm{C}$ and $1.5 \%$ respectively. Five males were anesthetized with benzocaine $(100 \mathrm{ppm})$ and the milt was collected by gentle abdominal pressure into a $200 \mu \mathrm{l}$ tips adapted for $1 \mathrm{ml}$ syringes positioned at the genital pore. Once filled, each tip was placed inside 1.5 $\mathrm{ml}$ tube and kept on ice. All the samples that showed maximum motility (index of 5, Strüssman et al., 1994) were collected in two pools of $100 \mu 1$. Sample 1 (S1) was directly processed for transmission electron microscopy (TEM)., sample 2 (S2) was diluted (1:5) with a Mounib modified solution $(127 \mathrm{mM}$ $\mathrm{NaHCO}_{3}, 159 \mathrm{mM}$ Sucrose, $0.025 \mathrm{~g} / \mathrm{ml}$ Reduced Glutathione; $\mathrm{pH} 8$; osmolality $400 \mathrm{mOsm} / \mathrm{Kg}$ ), and $10 \%$ of DMSO. Then, it was freeze in liquid $\mathrm{N}_{2}$ and after 24 hs was thawing following the methodology described in Lichtenstein et al. (2010), and then processed for TEM as it was described above.

Also, $1 \mu 1$ of fresh sperm was diluted in $500 \mu 1$ of $2 \%$ glutaraldehyide and dyed with $5 \%$ alcoholic eosin for $10 \mathrm{~min}$. Spermatozoa were observed and photographed using a light microscope (Nikon Eclipse E 600) attached to a digital camera (Nikon Digital Sight DS-U2).

\section{Transmission electron microscopy}

Sperm samples (S1 and S2) were fixed in 2\% glutaraldehyde in $0.2 \mathrm{M}$ phosphate buffer, $\mathrm{pH} 7.4$ (LADD Research Industries, Williston USA) for 2 hours at $4^{\circ} \mathrm{C}$. Then they were post fixed

Table 1. Measurements of the different parts of pejerrey spermatozoa (length, width and diameter) $\mathrm{n}=20$.

\begin{tabular}{ll}
\hline Name of the structure or microstructure & Mean \pm SE $(\mu \mathrm{m})$ \\
\hline Length of the head & $1.808 \pm 0.060$ \\
Width of the head & $1.673 \pm 0.066$ \\
Length of the midpiece & $1.115 \pm 0.032$ \\
Width of the midpiece & $1.565 \pm 0.050$ \\
Length of the flagellum & $29.084 \pm 1.242$ \\
Diameter of the flagellum & $0.373 \pm 0.053$ \\
Diameter of the flagellum with lateral extensions & $1.418 \pm 0.068$ \\
\hline
\end{tabular}



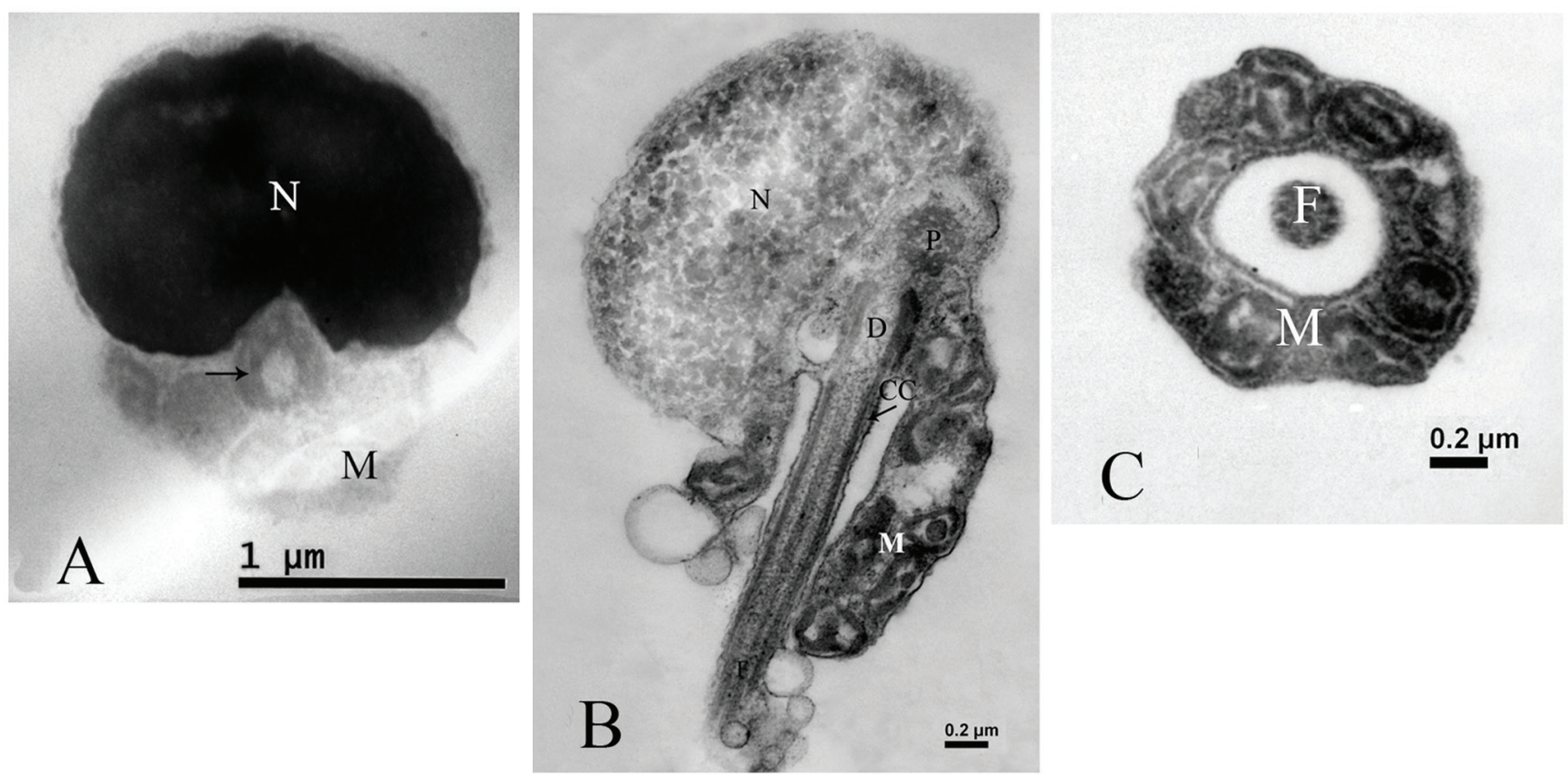

Fig. 2. Transmission electron microscopy photographs of fresh sperm samples: (A) Spermatozoa longitudinal section showing the transitional region of the flagellum and the classic nine doublets of microtubules (9+0), arrow. (B) Longitudinal section of the head and midpiece of a spermatid. (C) Transversal section of the midpiece showing the axoneme surrounded by mitochondria. N: Nucleus; P: Proximal centriole; D: Distal centriole; CC: Citoplasmic Channel; M: Mitochondria; F: Flagellum.

with $1 \%$ osmium tetroxide (LADD Research Industries, Willinston, USA) at $4^{\circ} \mathrm{C}$ and were dehydrated with an alcohol increasing series and embedded in resin Epoxi (LADD Research Industries, Willinston, USA). Ultrasections $(60 \mathrm{~nm})$ were put over copper grids, and stained with toluidine blue (Schmid GMBH \& CO, Krumbach, Germany). Then, they were stained with $2 \%$ uranyl acetate followed by lead citrate, and examined under a TEM Jeol JEM 1200 EX II. Morphological measurements were taken in 20 spermatozoa from S1 using Image Pro Plus 4.5 on the TEM photographs. Abnormalities were observed in the same way in 50 spermatozoa of each sample.

\section{Results}

Pejerrey spermatozoon is uniflagellated and differentiated into 3 parts: a small roundish head $(1,808 \pm 0,060 \mu \mathrm{m}$ in length and $1,673 \pm 0,066 \mu \mathrm{m}$ in width), a short midpiece or transitional region $(1,115 \pm 0,032 \mu \mathrm{m}$ in length and 1,565 $\pm 0,050 \mu \mathrm{m}$ in width), and a single long tail or flagellum $(29,084 \pm 1,242 \mu \mathrm{m}$; Fig. 1 and Table 1$)$. No acrosomal complex is present in the anterior part of the head. At ultrastructural level, the nucleus has a spherical shape with electron dense chromatin, granular and homogeneous in texture (Fig. 2a). The transitional region of the flagellum was the classical nine doublets of microtubules $(9+0$; Fig. 2a). Posterior to the nucleus it was possible to observe the centriolar complex where the proximal centriole remains apical and perpendicular to the distal centriole (Fig. 2b). In the midpiece it was observe the cytoplasmic channel in which lies the initial segment of the flagellum (Fig 2b). Surrounding this part of the flagellum it was possible to observe 4 to 7 mitochondria arranged in two layers (Fig. 2c).

The flagellum axoneme has the typical 9+2 structure with both dynein arms (Fig. 3a) and it was surrounded by a plasma membrane with lateral extensions like two fins (Fig. 3b). No vesicles were found along its extension (Fig 3c).

Under TEM different types of abnormalities were observed in sperm of both samples. However, these damages occurred at higher frequencies in the frozen thawed sperm (Fig. 4). While in fresh semen, 18\% of spermatozoa presented different types of morphological alterations; in thawed sperm this value was higher being around $60 \%$. There were spermatozoa with swollen, ruptured, or absent membranes in the head showing excess cytoplasm (Fig. 4a-c). When disorganize plasma membrane was found in the sperm, it was possible to observe the alteration of mitochondria position and in some cases the absence of these organelles (Fig. 4c).

As in the sperm head, swelling was observed in the flagellum and these often contained cytoplasmic vesicles, which were distributed along the whole length or concentrated in a restricted part of the tail (Fig. 4d). Spermatozoa head encircled by the tail was also seen as an often alteration (Fig. 4e). 


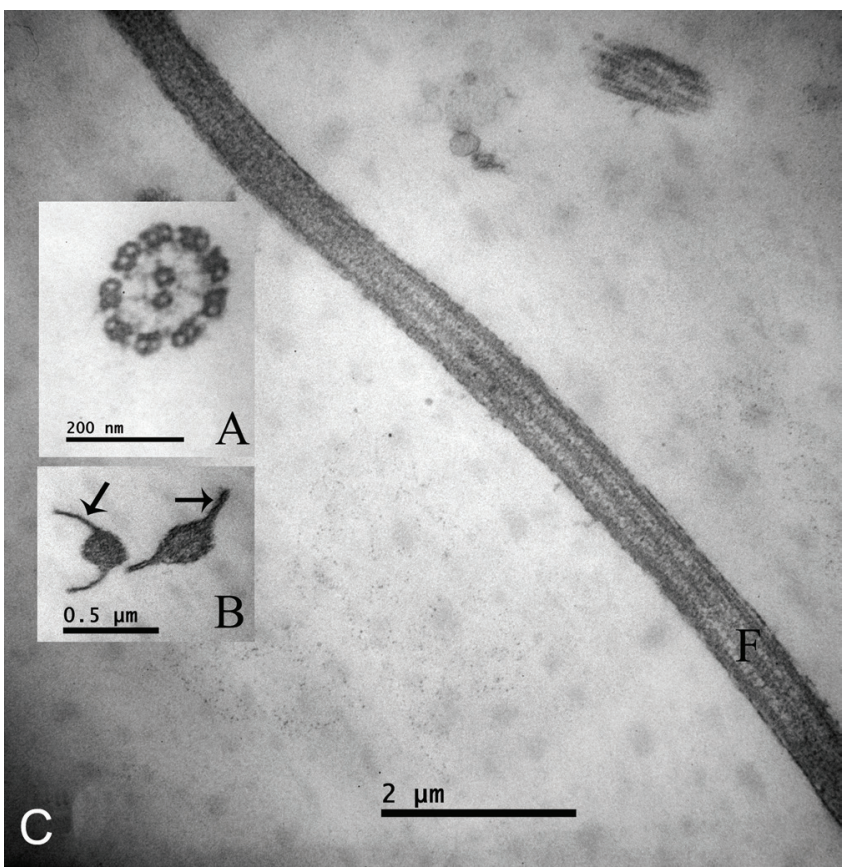

Fig. 3. Transmission electron microscopy photographs of the flagellum. (A) Flagellum axoneme showing the typical 9+2 doublets of microtubules. (B) Transversal section of the flagellum showing the lateral extensions like "fins" in both sides (arrows). (C) Longitudinal section of the flagellum. F: Flagellum.

\section{Discussion}

To our knowledge this is the first study showing the ultrastructural morphology of $O$. bonariensis sperm using electron microscopy techniques. The characteristics found in pejerrey sperm morphology were common for the Atheriniformes. This group of fish lacks an acrosome in the anterior part of the head, the nucleus is isodiametric with the chromatin usually flocculent, and in the midpiece, the mitochondria form a ring around the axoneme in one or two tier (between four to seven in number). An important characteristic of the spermatozoa of this order is that the flagellum bears two fins in almost all its length and the axoneme has the 9+2 pattern, apparently always with inner and outer dynein arms (Jamieson, 2009). Morphological descriptions of sperm as describe above are very useful to establish synapomorphies and phylogenetic relationships between groups as it was used for Mullidae and Siganidae families (Gwo et al., 2004a), or between species of Doradidae (Quagio-Grassiotto et al., 2011). Also, it can be used to describe and compare the spermiogenesis process in some species of Heptapteridae, Pseudopimelodidae, Pimelodidae (Quagio-Grassiotto et al., 2005; Quagio-Grassiotto \& Oliveira, 2008) and in some economically important fish species from Sinpercidae family (Luo et al., 2011).

In this context, Odontesthes genus has many species with a wide distribution in marine and inland waters of

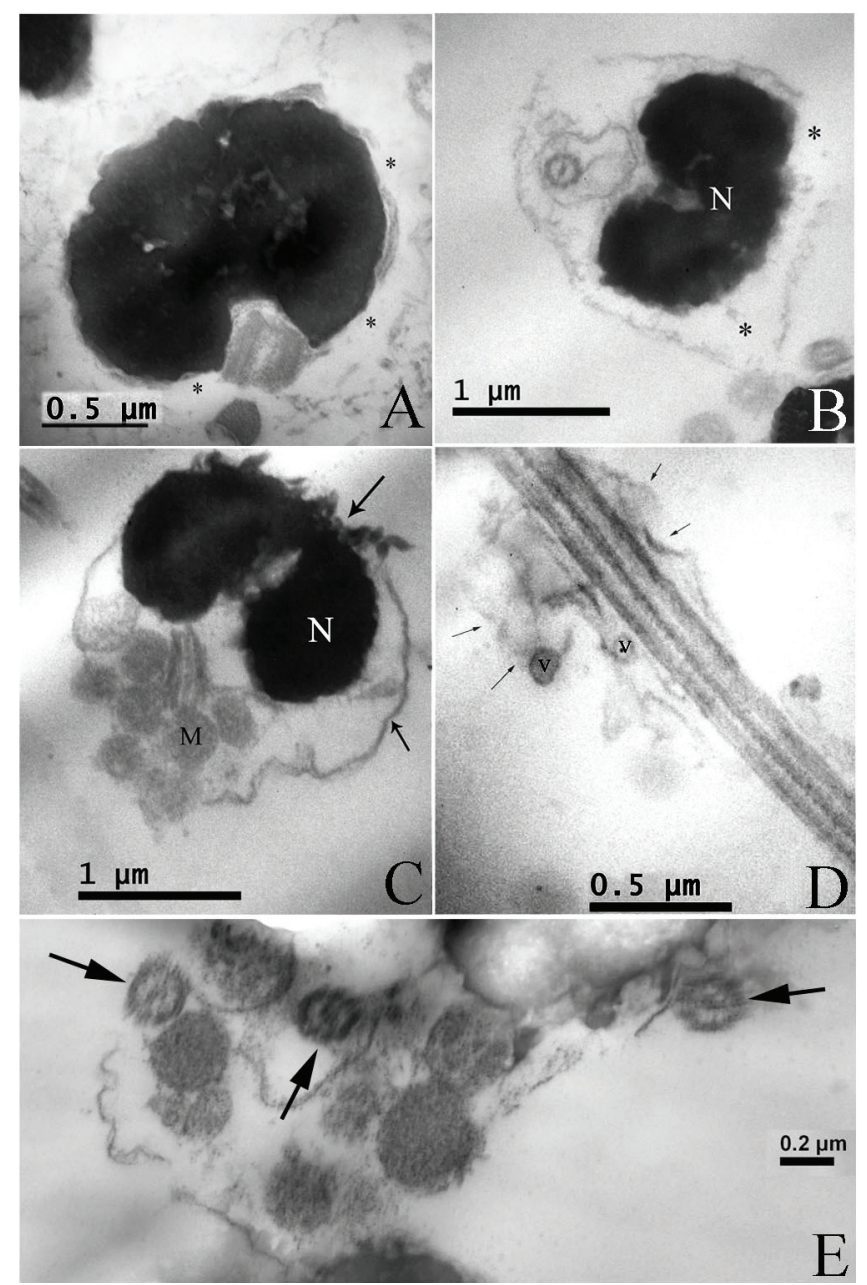

Fig. 4. Transmission electron microscopy photographs of pejerrey post thawed sperm showing different types of alterations. (A) Head with ruptured membranes (*). (B) Head with swollen and broken membrane (*). (C) Broken and swollen nuclear membrane (arrows) and alteration of the spatial orientation of mitochondria. (D) Ruptured and swollen membrane of the flagellum (arrows) with vesicles. (E) Tail around the head (arrows). N: Nucleus; M: Mitochondria; V: Vesicles.

South America (Dyer, 2006) and these kinds of spermatozoa descriptions could be useful to establish better phylogenetic relationships between species of this genus. In pejerrey fresh spermatozoa, some morphological alterations as rupture head membranes, and changes in the position of mitochondria were observed. After cryopreservation treatment, swollen of the head, flagellum which often containing cytoplasmatic vesicles, and the tail surrounding the head were found. In other fish orders, another kind of alterations were reported as lost or dilated mitochondria, swollen midpiece, and broken or double tails (Taddei et al., 2001; He \& Woods, 2004; Alavi et al., 2008). All these cellular damages could be compromising the sperm motility, but does not necessary mean that the fertilization rate is affected. In this sense, it has been reported 
that immotile post thawed spermatozoa of common carp and Atlantic croaker were capable of fertilization (Billard, 1988; Warnecke \& Pluta, 2003; Gwo et al., 1991). It was also described that the integrity of the cellular membrane is important for the sperm viability and it is the primary site of cooling and warming injury (Morris, 1981). The resistance of spermatozoa to cooling is influenced by the biochemical composition of their membranes (Darin-Bennet et al., 1977). In marine fish, spermatozoa were more resistant to freezing than those of freshwater fish due to the higher content of phospholipids and lower polyunsaturated fatty acids (DarinBennet et al., 1977; Drokin, 1993). In addition to membrane destabilization, physical damage to the nuclear membrane can result from the formation of ice crystals within the cell (Taddei et al., 2001) and in the external medium, by osmotic stress or oxidative stress (see Cabrita et al., 2010). Cellular osmoregulation also could be compromised resulting in swelling of the head and tail, and secondary injuries to other intracellular organelles could determinate displacement or loss of functionality of mitochondria and outflow of the chromatin (Taddei et al., 2001). So the conservation of cell structure and functionality will depend on the cryopreservation protocol (Cabrita et al., 2010).

Another cause of this sort of damages could be related to the toxicity of the crioprotector used and its concentration. In pejerrey, it was demonstrated that DMSO is a suitable cryoprotectant for cryopreserving sperm (Lichtenstein et al., $2010)$ as it was also reported in many studies, probable due to its fast penetration into spermatozoa and its interaction with the phospholipids at the sperm membrane (Kerby, 1983; Suquet et al., 2000; He \& Woods, 2003, 2004). The fertilization rates obtained after cryopreservation using DMSO in pejerrey criopreserved milt were around $60 \%$ (Lichtenstein et al., 2010). However, some of the morphological alterations observed in this study, cannot be exclusively ascribed to cryopreservation procedure because they are present in fresh sample too, but at lower frequencies. These damages may be also related to the fixation procedures for TEM, especially in the case of the integrity of the sperm head membrane (Taddei et al., 2001).

In conclusion, the morphology of pejerrey sperm has been described for the first time showing characteristics of the Atheriniformes. The morphological alterations described in this work could be caused for a combination of cryopreservation and fixation procedures for microscopic observations, and could be related to the diminution in fertility rates found using post thawed sperm.

\section{Acknowledgments}

This work was supported by ANPCyT, PICT 2007 (1181) and CONICET, PIP Res. D. N¹673/12 to LAM.

\section{Literature Cited}

Alavi, M. H., M. Psenicka, T. Policar \& O. Linhart. 2008. Morphology and fine structure of Barbus barbus (Teleostei: Cyprinidae) spermatozoa. Journal of Applied Ichthyology, 24: 378-381.

Billard, R. 1988. Artificial insemination and gamete management in fish. Marine Behaviour and Physiology, 14: 3-21.

Bloom, D. D., P. J. Unmack, A. E. Gosztonyi, K. R. Piller \& N. R. Lovejoy. 2012. It's a family matter: Molecular phylogenetics of Atheriniformes and the polyphyly of the surf silversides (Family: Notocheiridae). Molecular Phylogenetics and Evolution, 62: 1025-1030.

Cabrita, E., R. Alvarez, R. Anel, K. J. Rana \& M. P. Herraez. 1998. Sublethal damage during cryopreservation of rainbow trout sperm. Cryobiology, 37: 245-253.

Cabrita, E., C. Sarasquete, S. Martınez-Paramo, V. Robles, J. Beirao, S. Perez-Cerezales \& M. P. Herraez. 2010. Cryopreservation of fish sperm: applications and perspectives. Applied Ichthyology. 26, 623-635.

Darin-Bennet, A. \& I. G. White. 1977. Influence of the cholesterol content of mammalian spermatozoa on susceptibility to cold shock. Cryobiology, 24: 466-470.

Drokin, S. I. 1993. Phospholipid distribution and fatty acid composition of phosphatidylcholine and phosphatphosphatidylethanolamine in sperm of some fresh water and marine species. Aquatic Living Research, 6: 49-56.

Dyer, B. S. 2006. Systematic revision of the South American silversides (Teleostei, Atheriniformes). Biocell, 30: 69-88.

Dyer, B. S. \& B. Chernoff. 1996. Phylogenetic relationships among atheriniform fishes (Teleostei, Atherinomorpha). Zoological Journal of Linnean Sociey London, 117: 1-69.

França, G. F., C. Oliveira \& I. Quagio-Grassiotto. 2007. Ultrastructure of spermiogenesis and spermatozoa of Gymnotus cf. anguillaris and Brachyhypopomus cf. pinnicaudatus (Teleostei: Gymnotiformes). Tissue and Cell, 39: 131-139.

Gwo, J. C., H. H. Gwo \& S. L. Chang. 1992. The spermatozoon of the Japanese eel, Anguilla japonica (Teleostei, Anguilliformes, Anguillidae). Journal of Submicroscopic Cytology and Pathology, 24: 571-574.

Gwo, J. C., M. C. Kuo, J. Y. Chiu \& H. Y. Cheng. 2004b. Ultrastructure of Pagrus major and Rhabdosargus sarba spermatozoa (Perciformes: Sparidae: Sparinae). Tissue and Cell, 36: 141-147.

Gwo, J. C., K. Strawn, M. T. Longnecker \& C. R. Arnold. 1991. Cryopreservation of Atlantic croaker spermatozoa. Aquaculture, 94: 355-375.

Gwo, J. C., W. T. Yang, M. C. Kuo, A. Takemura \& H. Y. Cheng. 2004a. Spermatozoal ultrastructures of two marine perciform teleost fishes, the goatfish, Paraupeneus spilurus (Mullidae) and the rabbitfish, Siganus fuscescens (Siganidae) from Taiwan. Tissue and Cell, 36: 63-69.

He, S. \& L. C. Woods III. 2003. The effects of osmolality, cryoprotectant and equilibration time on striped bass sperm motility. Journal of World Aquaculture Society, 34: 255-265.

He, S. \& L. C. Woods III. 2004. Changes in motility, ultrastructure, and fertilization capacity of striped bass Morone saxatilis spermatozoa following cryopreservation. Aquaculture, 236: 677-686.

Jamieson, B. G. M. 2009. Reproductive Biology and Phylogeny of Fish (Agnatha and Osteichthyes): Phylogeny, Reproductive System, Viviparity, Spermatozoa. Enfield, Science Publishers. 
Kerby, J. H. 1983. Cryogenic preservation of sperm from striped bass. Transactions of the American Fisheries Society, 112: 86-94.

Lahnsteiner, F., B. Berger, T. Weismann \& R. A. Patzner.1996. Changes in morphology, physiology, metabolism, and fertilization capacity of rainbow trout semen following cryopreservation. Progressive Fish Culturist, 58: 149-159.

Lichtenstein, G., M. Elisio \& L. A. Miranda. 2010. Development of sperm cryopreservation techniques in pejerrey Odontesthes bonariensis. Aquaculture, 306: 357-361.

López, H., C. Baigún, J. Iwaskiw, R. Delfino \& O. Padín. 2001. La cuenca del Salado: Uso y posibilidades de sus recursos pesqueros. La Plata, Ed. Univ. La Plata.

Mattei, X. 1991. Spermatozoon ultrastructure and its systematic implications in fishes. Canadian Journal of Zoology, 69: 3038-3055.

Miranda, L. A., G. E. Berasain, C. M. Velasco, Y. Shirojo \& G. M. Somoza. 2006. Natural spawning and intensive culture of pejerrey Odontesthes bonariensis juveniles. Biocell, 30: 89-95.

Miranda, L. A. \& G. M. Somoza. 2009. Spawning induction of pejerrey Odontesthes bonariensis in captivity using sustainedrelease gonadotropin releasing hormone agonist implants. Aquaculture Research, 41: 129-134.

Miranda, L. A., M. C. Cassará \& G. M. Somoza. 2005. Increase of milt production by hormonal treatment in the pejerrey fish Odontesthes bonariensis. Aquaculture Research, 36: 1473-1479.

Miranda, L. A., R. U. Escaray, J. F. Bustingorry \& G. M. Somoza. 2001. Effects of photoperiod and human chorionic gonadotropin (hCG) administration on spermiation in pejerrey Odontesthes bonariensis. Revista Argentina de Producción Animal, 21: 95-105.

Morris, G. J. 1981. Liposomes as a model system for investigating freezing injury. In: Morris, G. J. \& A. Clarke (Eds.). "Effects of Low Temperatures on Biological Membranes". New York, Academic Press, 214-262.

Quagio-Grassiotto, I., M. A. Spadella, M. Carvalho \& C. Oliveira. 2005. Comparative description and discussion of spermiogenesis and spermatozoa ultrastructure in some species of Heptapteridae and Pseudopimelodidae (Teleostei: Siluriformes). Neotropical Ichthyology, 3: 401-410.

Quagio-Grassiotto, I. \& C.Oliveira. 2008. Sperm ultrastructure and a new type of spermiogenesis in two species of Pimelodidae, with a comparative review of sperm ultrastructure in Siluriformes (Teleostei: Ostariophysi). Zoologischer Anzeiger, 247: 55-66.
Quagio-Grassiotto, I., R. J. Ortiz, M. H. Sabaj Pérez \& C. Oliveira. 2011. Sperm of Doradidae (Teleostei: Siluriformes). Tissue and Cell, 43: 8-23.

Rodriguez-Martinez, H. \& H. Ekwall. 1998. Electron microscopy in the assessment of cryopreserved spermatozoa viability. European Microscopy Analysis, 65: 25-27.

Somoza, G. M., L. A. Miranda, G. E. Berasain, D. Colautti, M. Remes Lenicov \& C. A. Strüssmann. 2008. Historical aspects, current status, and prospects of pejerrey aquaculture in South America. Aquaculture Research, 39: 784-793.

Strüssmann, C. A. 1989. Basic studies on seed production of pejerrey Odontesthes bonariensis. Ph.D. Dissertation, Tokyo, Tokyo University of Fisheries, 351p.

Strüssmann, C. A., P. Renard, H. F. Ling \& F. Takashima. 1994. Motility of pejerrey Odontesthes bonariensis spermatozoa. Fisheries Science, 60: 9-13.

Suquet, M., C. Dreanno, C. Fauvel, J. Cosson \& R. Billard. 2000. Cryopreservation of sperm in marine fish. Aquaculture Research, 31: 231-243.

Taddei, A. R., F. Barbato, L. Abelli, S. Canese, F. Moretti, K. J. Rana, A. M. Fausto \& M. Mazzini. 2001. Is Cryopreservation a Homogeneous Process? Ultrastructure and Motility of Untreated, Prefreezing, and Post thawed Spermatozoa of Diplodus puntazzo (Cetti). Cryobiology, 42: 244-255.

Tsuzuki, M. Y., H. Aikawa, C. A. Strüssmann \& F. Takashima. 2000. Comparative survival and growth of embryos, larvae, and juveniles of pejerrey Odontesthes bonariensis and O. hatcheri at different salinities. Journal of Applied Ichthyology, 16: 126-130.

Warnecke, D. \& H. J. Pluta. 2003. Motility and fertilizing capacity of frozen/thawed common carp (Cyprinus carpio L.) sperm using dimethy-acetamide as the main cryoprotectant. Aquaculture, 215: 167-185.

Yao, Z., L. W. Crim, G. F. Richardson \& C. J. Emerson. 2000. Motility, fertility and ultrastructural changes of ocean pout (Macrozoarces americanus L.) sperm after cryopreservation. Aquaculture, 181: 361-375.

Submitted April 12, 2013

Accepted October 7, 2013 by Clarice Fialho Published December 27, 2013 